\title{
DOUBLE ELECTRICAL LAYER IN THE CATHODE SPOT
}

\author{
Leonid I. Gretchikhin ${ }^{a}$, Svetlana D. Latushkina ${ }^{\mathrm{b}}$, \\ Viktoryia M. Kamarouskaya ${ }^{\mathrm{C}}$ \\ ${ }^{a}$ Belarusian State Academy of Communications, Minsk, Republic of Belarus, \\ e-mail: Gretchihin@yandex.ru, \\ ORCID iD: (Dhttp://orcid.org/0000-0002-5385-9037 \\ ${ }^{\mathrm{b}}$ Physical Technical Institute, National Academy of Sciences, \\ Minsk, Republic of Belarus, \\ e-mail: phti@tut.by, \\ ORCID iD: @orcid.org/0000-0001-5390-0991 \\ ${ }^{\mathrm{b}}$ Belarusian National Technical University, Minsk, Republic of Belarus, \\ e- mail: maratovna81@tut.by \\ ORCID iD: (Dhttp://orcid.org/0000-0001-8925-6421
}

DOI: 10.5937/vojtehg64-9851

\begin{abstract}
FIELD: Materials Science at the Nanolevel ARTICLE TYPE: Original Scientific Paper ARTICLE LANGUAGE: English
\end{abstract}

\begin{abstract}
:
The paper describes a new phenomenon of the generation of the double electrical layer above the cathode spot surface. The neutralization of this layer leads to the reverse current of free electrons, generated due to negative ions ionization. The negatively charged flame of the cathode spot periodically ignites and attenuates, so the duration of the cathode spot existence is defined by this oscillating process. The reverse motion of the cathode spot in the longitudinal magnetic field takes place owing to the generation of the reverse high-power neutralization current of the double electrical layer by the electrons appearing during the negative ions ionization in the cathode flame.
\end{abstract}

Key words: electric discharge, cathode spot, cathode flame, negative ions, double electrical layer.

\section{Introduction}

The vacuum plasma coatings technique is widely used for constructional materials hardening and friction force decreasing (Baldaev, Borisov, Vachalkin, 2007), (Mrochek, Vershina, Ivashchenko, et al, 2004), (Grigoryants, 1989). The ion plasma technique is mainly applied for the 
vacuum plasma coatings deposition. In this case, the vacuum arc burns in the plasma material of the cold cathode due to its discharge current sputtering. This technique is quite complicated to be applied as it is difficult to determine the processes taking place inside the cathode spot and which plasma composition can occur in the cathode flames of the arc discharge.

The processes occurring inside the cathode spot were studied in detail by (Kesaev, 1968). As a result, the fundamental characteristics of the cathode spots were determined as well as the main directions of further investigations. The spectroscopic investigations of the cathode spots and the explosive processes occurring in the cathode flames were specially investigated by Kesaev. He investigated in detail the effect found by Shtark in 1903, where the cathode flames in the tangential magnetic field are not deflected in accordance with Ampere's law (even nowadays this effect has no convincing explanation).

The problems raised by Kesaev are solved to a certain extent, but not completely. The spectroscopic investigations of the cathode flames of the arc and sparkle discharges were carried out by Gretchikhin together with colleagues in the middle of the 1960s and it is shown that the plasma generation in the cathode flames is determined by the presence of negative ions inside the flames (Gretchikhin, Tyunina, 1967), (Gretchikhin, Davydov, Minko, Ya, 1968 ), (Gretchikhin, 1974).

The explosive processes investigations in the cathode flames were carried out by Mesyats with colleagues and it was found that micro explosions can be generated inside the cathode spots on separated low-sized particles, called ectons, (Mesyats, 2000), (Mesyats, 1993), (Mesyats, 1995).

During the vacuum plasma technique development, some new problems appeared, such as: 1 - why there is the presence of the liquid phase under micro explosions in the cathode spot; 2 - what processes determine the electron energy distribution, and, consequently, why the percentage ratio of the ions with a different degree of ionization does not correspond to Saha equation; 3 - why the cathode flames under the longitudinal magnetic field application do not deflect in accordance with Ampere's law, etc. In this regard, there is a goal to develop the model of erosion plasma generation which could quite convincingly describe the character of the plasma generation in the high-current vacuum arc. So, the following actions should be taken to solve the given tasks:

- to develop the exact model of the micro explosion in the cathode spot with regard to negative ions generation;

- to study the effect considering the cathode spot heating and liquid phase generating;

- to find out the processes leading to the electronic component plasma heating and to prove the percentage ions composition in the cathode flame in accordance with experimental data; and 
- to find the cause of the reverse motion of the cathode flame in the longitudinal magnetic field.

Therefore, we consistently considered all the raised issues as applied to the erosion plasma of the cathode spots.

\section{Negative ions in the explosive processes}

Only the external atoms of the separate cathode material cluster are in contact with surrounding atoms during an explosion in the cathode spot. Cluster ionization energy is lower than $2 \mathrm{eV}$ (Gretchikhin, 2008), while the energy of the electron affinity of an atom is slightly lower (Messi, 1979). Under the melting point, due to the tunnel-effect, the valence electrons of the surrounding atoms and clusters transverse to the atoms of the explosive cluster. The cluster is split onto separate free atoms in the moment of explosion. The built-in dipole electrical moments of the free atoms in the electric field of the cathode potential drop are lined in the field so the positive charge is in contact with the cathode material surface. The energetic scheme of the cluster atom interaction with the cathode surface is shown in Fig.1. The probability of this is determined by the transparency ratio of the potential barrier during the tunnel-effect:

$$
W=\frac{n_{a}^{-}}{n_{a}}=\exp \left[-\frac{4 \pi d}{h} \sqrt{2 m_{e}\left(E_{1}-E_{2}\right)}\right],
$$

where $d=r_{\mathrm{a}}-r_{\mathrm{k}}$-difference between the atom radius and its covalent radius; $E_{1}$ - cluster energy ionization of the cathode material; $E_{2}$ - energy of the electron affinity of an atom; $m_{\mathrm{e}}$ - electron mass.

As an example, the following cathode materials can be examined: iron, titanium, and copper ${ }^{1}$.

Not all of the cluster atoms of the surface layer are directly in contact with atoms and clusters of the surroundings. Taking this into consideration, the general probability of the fact that titanium atoms leave the cathode spot by means of negative ions is:

$$
W_{\text {gen. }}=\frac{N_{c l .}-\Delta N_{c l}}{N_{c l .}} W
$$

Here $N_{\text {cl. }}$ - general number of particles in the cluster and $\Delta N_{c l}-$ number of particles of the surface layer which are not in direct contact with surrounding atoms of the cathode material.

${ }^{1}$ The choice of these materials is explained by the difference in the crystal structure. 

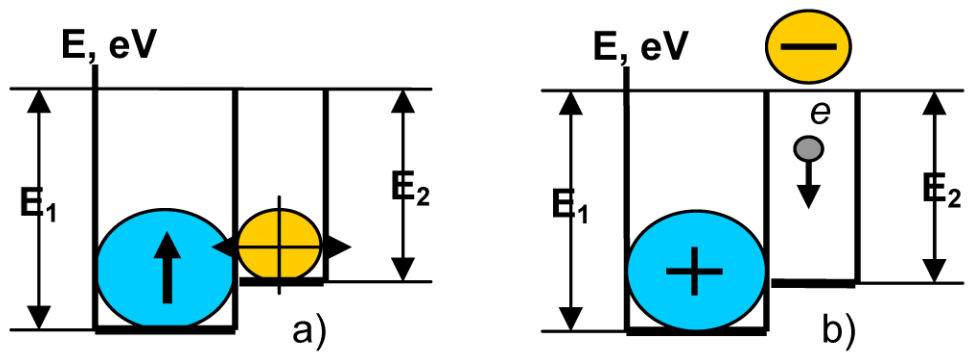

Figure 1 - Scheme of the negative ions generation in the cluster explosion process:

a) - model of the cluster atoms interaction with the substrate and b) - model of the electrical charge separation during vapor ejection after a cluster explosion

Puc. 1 - Схема образования отрицательных ионов в процессе взрыва кластера: а) - модель взаимодействия атомов кластера с основой и б) - модель разделения электрических зарядов при выбросе пара после взрыва кластера

Slika 1 - Šema obrazovanja negativnih jona tokom procesa eksplozije klastera a) - model interakcije atoma klastera sa substratom i b) - model separacije naelektrisanja tokom izbacivanja pare nakon eksplozije klastera

For example, iron clusters have the bcc structure, where there are 9 diatomic molecules, out of which only 4 molecules are in contact with the cathode material. The cluster radius is $r_{c l}=3.78 \AA$, the cluster ionization potential $-E_{1}=1.46 \mathrm{eV}$ (Gretchikhin, 2008), the negative ion potential $E_{2}=0.163 \mathrm{eV}$, and the difference between the atom radius and the covalent radius is $-d=r_{a}-r_{k}=0.455 \AA$. On the basis of these data, the concentration of negative iron ions in the cathode flame of the vacuum arc is $W_{\text {gen. }} \sim 0.261$

Titanium clusters have the fcc close-packed structure, where only 9 from 13 triatomic molecules are directly in contact with the surroundings. So only these 9 molecules are negative ions, and the cluster radius is $r_{c l}$. $=4.38 \AA$, the cluster ionization potential $-E_{1}=1.53 \mathrm{eV}$, th e negative ion potential $-E_{2}=0.079 \mathrm{eV}$ and $W_{\text {gen }} \approx 0.115$.

Copper clusters have the fcc structure, where there are 13 triatomic molecules, out of which only 8 molecules are in contact with particles from the surroundings. The cluster radius is $r_{c l}=3.84 \AA$, the cluster ionization potential $-E_{1}=1.633 \mathrm{eV}$ (Gretchikhin, 2008), the negative ion potential $-E_{2}=1.228 \mathrm{eV}$, and the difference between the atom radius and the covalent radius $-d=r_{a}-r_{k}=0.482 \AA$. On the basis of these data, the concentration of negative copper ions in the cathode flame of the vacuum arc is $W_{\text {gen. }} \sim 0.150$ 
The passage of discharge current of the cluster length, i.e. its diameter is:

$$
\tau=2 r_{c l .} / v=2 \cdot r_{c l .} \cdot \sqrt{\varepsilon_{r}} / c, \text { sec. }
$$

Here $r_{c l}$ - the minimum radius with a separate emissive cell in the cathode spot i.e. the cluster radius, $c$-speed of light in vacuum, and $\varepsilon_{r}$ relative dielectric medium permeability.

The electric polarization theory for metals was developed by (Gretchikhin, Physics, 2008) and the calculations were made for the relative permeability for natrium, aluminum, iron and copper, while the relative dielectric permeability for titanium was calculated separately and was $\varepsilon_{r} \sim 3.965 \cdot 10^{13}$. On the basis of (3), the passing time of the electromagnetic wave through the cluster is $\tau-1.085 \cdot 10^{-11} \mathrm{sec}$ for iron, $\tau=1.84 \cdot 10^{-11} \mathrm{sec}$ for titanium and $\tau=5.51 \cdot 10^{-11} \mathrm{sec}$ for copper.

This time is necessary for the cluster to absorb discharged current energy. Since the process time is $\sim(1 \div 5) \cdot 10^{-11} \mathrm{sec}$, the cluster destruction process has an explosive behavior. The pressure, emerging at the cluster explosion moment, can be calculated by the formula:

$$
P_{\max .}=\frac{N_{c l .}}{\left(2 \cdot r_{c l .}\right)^{3}} k_{B} T_{b o i l .}
$$

Here $N_{\text {cl. }}$ - number of cluster particles multiplied by the number of atoms in the particle. Considering the overall atoms number in the cluster, the pressure at the cluster explosion inside the cathode spot is $1.82 \cdot 10^{9} \mathrm{~Pa}$ for iron, $1.98 \cdot 10^{9} \mathrm{~Pa}$ for titanium and $3.35 \cdot 10^{9} \mathrm{~Pa}$ for copper. Such pressure values can occur during the explosive blast (Gretchikhin, Rubleva, 2006), (Litvinskiy, 2006).

During the cluster explosion, a number of negatively charged particles are emitted from the cathode spot ${ }^{2}$. In this case, the electric current density of the charge separation during the flame discharge in the cluster explosion with double electrical layer generation is:

$$
j_{k}=\frac{N_{c l} W_{g e n} e}{V_{c l}} v_{f}
$$

where $V_{c l}$ - the cluster volume and $v_{f}$ - the flame emission rate from the cathode spot and it is determined by using the point explosion model.

2 The attention was paid to this effect in the late 19th and at the beginning of 20th century (Kesaev, 1968). 
The shock wave rate in solids for the point explosion is determined by the formula (Korobeinikov V. P., Melnikova N.S., Ryazanov E.V. 1961) and (Kostenboim X.S. 1974)

$$
v_{\text {sh.w. }}=\frac{2}{5}\left(\frac{E_{0}}{\alpha^{\prime} \rho_{c}}\right)^{1 / 2} \frac{1}{r_{c l .}^{3 / 2}},
$$

where $\alpha^{\prime} \approx 0.851, E_{0}$ - energy emitted in the cluster during the current discharge flow and $\rho_{\mathrm{c}}-$ the cathode material density.

The energy emitted in the cluster is:

$$
W_{k}=L_{\max } \frac{\pi d_{k}^{2}}{4} \tau, \mathrm{J}
$$

where $L_{\max }$ - the Poynting vector, $d_{K}$ - the cathode spot size and $\tau$ - the electromagnetic wave passage time through the cathode material cluster.

On the basis of the cathode spot "autographs", it is shown in this work (Kesaev I.G. 1968) that the cathode spot diameter is increased due to arc current and film thickness. When the arc current and films thickness are quite small, the ratio of the discharge current to the "autograph" width is sufficiently small, and it is stabilized with a current and film thickness increase. When the arc current and films thickness are high, the ratio of the discharge current to the "autograph" width increases quickly. In the first case, not all the discharge current power is used for the film evaporation, while under the high currents and film thicknesses the spot size significantly enlargers due to "autographs" edges melting. Taking this into consideration, the probable "autograph" size of the separate copper cathode spot is $(1 \div 2) \cdot 10^{-5} \mathrm{~m}$ (the average value for further evaluations is $d_{k}=1.5 \cdot 10^{-5} \mathrm{~m}^{3}$ ).

The cathode spot is only influenced by the arc discharge current, so the average current density is $-J_{k}=4 I / \pi d_{k}^{2}$.

In this case, the Poynting vector is defined by the Joule law

$$
L_{\max }=J_{k} U_{k} \text {, }
$$

where $U_{k}$ - a near-cathodic potential drop. The average values of the near-cathodic potential drop are listed here (Kesaev, 1968) and it is quite

\footnotetext{
${ }^{3}$ Since the magnetic pressure of the current discharge is equal to the gas-kinetic pressure in the cathode flame, then the pressure in the cathode flame at this spot diameter $\sim 9.0 \cdot 10^{5} \mathrm{~Pa}$. Such a quick pressure drop in the cathode flame while exiting the cathode spot is caused by the discharge-like "vacuum expansion".
} 
convincingly shown that this potential drop coincides with first atoms ionization potential of the cathode materials for most metals.

As a result, the flame discharge rate of the cathode flame can be calculated by means of the point explosion model and it is $4324 \mathrm{~m} / \mathrm{s}$ for iron, $4652 \mathrm{~m} / \mathrm{s}$ for titanium and $7820 \mathrm{~m} / \mathrm{s}$ for the copper cathode. During cathode processes modeling of the pulsed discharge by laser, the flame discharge rate at some distance from the surface turned out to be $3900 \mathrm{~m} / \mathrm{s}$ (Gretchikhin, Minko, 1967), while in the vacuum arc $-12.5 \mathrm{~km} / \mathrm{s}$ under an arc current of $115 \mathrm{~A}$ (Kesaev, 1968). The flame discharge rate was $8.8 \mathrm{~km} / \mathrm{s}$ for the iron cathode under an arc current of 142 A (Kesaev, 1968), while these investigations were not carried out for the titanium cathode. 1968). The found values are quite reliable and they can be used in further calculations. Then the current density, caused by the negative ions discharge from the cathode spots is $\sim 4.6 \cdot 10^{12} \mathrm{~A} / \mathrm{m}^{2}$ for the titanium cathode spot, $\sim 1.37 \cdot 10^{13} \mathrm{~A} / \mathrm{m}^{2}$ for iron and $\sim 1.3 \cdot 10^{13} \mathrm{~A} / \mathrm{m}^{2}$ for copper. Exactly the same current densities were experimentally found during the ecton explosion (cluster) (Mesyats, 2000), (Mesyats, 1993) and (Mesyats, 1995).

The energy to be transferred to the cluster to disintegrate it into separate atoms is:

$$
\Delta Q=\frac{m_{c l .}}{\mu} \Delta H_{b o i l}
$$

where $m_{c l}$ - the cluster mass, $\mu$ - the cathode material molar mass $\Delta H_{\text {boil. }}$ the sublimation heat. This energy is $1.75 \mathrm{eV}$ for the iron cluster, $3.46 \mathrm{eV}$ for the titanium one and $1.92 \mathrm{eV}$ for the copper one. Using these values of energy, it is possible to determine the maximum current density which leads to the complete cluster disintegration into separate atoms by the formula:

$$
j_{\max .}=\frac{\Delta Q}{U_{k} S_{k} \tau_{k}} .
$$

Here $U_{k}, S_{k}$ and $\tau_{k}$ - the cathode potential drop, the cluster area and the passage time of the cluster length by the discharge current, respectively. The near-cathodic potential drops are listed here (Kesaev, 1968) and (Kolesnik, Kolesnik, 2009), while the cluster radius values are given in (Gretchikhin, 2008). The passage time is determined by the rate of the electromagnetic waves in the cathode material and is equal to $\tau_{k}=2 r_{c l} \cdot \sqrt{\varepsilon_{r}} / c \quad\left(\varepsilon_{r}\right.$ - relative dielectric permeability of the cathode material and $c$ - the speed of light). The limit current density leading to the complete 
cluster destruction is respectively $1.4 \cdot 10^{9} \mathrm{~A} / \mathrm{m}^{2}$ for the iron cluster, $2.3 \cdot 10^{9}$ $\mathrm{A} / \mathrm{m}^{2}$ for titanium and $4.7 \cdot 10^{8} \mathrm{~A} / \mathrm{m}^{2}$ for copper. Therefore, the current density emerging during the cathode cluster explosion in the vacuum arc is significantly higher than the current density of complete cluster destruction. The average current density on the cathode spot is about $\sim 10^{12} \mathrm{~A} / \mathrm{m}^{2}$ when the discharge current is $100 \mathrm{~A}$. The clusters of almost all cathode materials explode and disintegrate into separate atoms under this current density and they are discharged as a vapor-gas phase from the cathode spot.

The electric current is generated by every cluster explosion $I_{k}=j_{k} S_{k}$, and the number of clusters to be exploded simultaneously in the cathode spot is $-n_{k}=I / I_{k}=I / j_{k} S_{k}$. When the current discharge is $100 \mathrm{~A}$, the total number of clusters is $n_{k}=2.86 \cdot 10^{7}$ for the titanium cathode, $n_{k}=1.63 \cdot 10^{7}$ for iron and $n_{k}=1.32 \cdot 10^{7}$ for copper. When the cathode spot diameter is $10^{-5} \mathrm{~m}$, the total number of clusters is $n_{k, n}=$ $1.3 \cdot 10^{8}$ for the titanium cathode, $n_{k, n}=1.75 \cdot 10^{8}$ for iron and $n_{k, n}=$ $1.7 \cdot 10^{8}$ for copper. It should be no more than 5 erosion cells for the titanium cathode, no more than 10 for the iron cathode and no more than 12 for the copper cathode under a current discharge of $100 \mathrm{~A}$ (Kolesnik, Kolesnik, 2009). It was found that the number of erosion cells in the cathode spot was within 4-12, depending on the discharge conditions. This is confirmed by estimations on the basis of negative ions emission.

The electric current is generated by every exploded cluster, and all these currents produce the emission cell with public electric current which is equal to the current discharge to that fact. Owing to this, parallel currents are integrated by the Ampere force, and this effect is called current discharge pinching.

During the clusters explosion, the electric current is conducted by negative ions, but not free electrons. The magnitude of the pulse current during every separate cluster explosion corresponds to experimental data, found by (Mesyats, 2000), (Mesyats, 1993) and (Mesyats, 1995).

The negative ions ionization takes place during flame discharging. Free electrons can be generated and they try to neutralize the positive charge on the cathode spot surface. The reverse electric current can be generated and its value is several times higher than the main discharge current.

The enormous reverse current is caused by the free electron flow and this flow is spread all over the whole cathode spot area. Having passed the near-cathodic potential drop, these electrons penetrate into the skin depth and transform this layer into a liquid film. 


\section{Liquid phase generation in the cathode spot}

During a cluster explosion, the explosive emission of the negative charge from the cathode is defined by the electric current conducted not by free electrons, but by negative ions. At the same time, the positive charge is by the negative charge flame, and the double electrical layer is formed. The negative ions disintegration in the vacuum arc electric discharges takes place owing to the following reactions:

$$
\begin{aligned}
& A^{-}+B \Leftrightarrow A B+e ; \\
& A^{-}+e \Leftrightarrow A+2 e .
\end{aligned}
$$

Both reactions (11) occurred in the vapor-gas phase. Based on the first reaction, the concentration of generated free electrons per unit time is equal to:

$$
\frac{d n_{e}}{d t}=k_{f} n_{a}^{-} n_{a}^{\prime}=k_{f} W_{\text {gen. }}\left(1-W_{\text {gen. }}\right) n_{a}^{2} .
$$

Here $k_{f}-$ the constant of the first direct reaction (11). The activation energy of the fist reaction (11) is determined by the empiric formula (Benson S., 1962).

$$
E_{a}=0,29 D-22,2 \mathrm{KJ} / \mathrm{mole} \text {, }
$$

where $D$ - the dissociation energy of the formed diatomic molecule $(A B)$. The dissociation energy is $1.2 \mathrm{eV}$ for $\mathrm{Ti}_{2}$, and $-2.05 \mathrm{eV}$ for $\mathrm{Cu}_{2}$ (Radtsig, Smirnov, 1980). So the activation energy is $11.38 \mathrm{~kJ} / \mathrm{mole}$ for titanium, and $35.16 \mathrm{~kJ} / \mathrm{mole}$ for copper. The constant of the direct chemical reaction (Benson S., 1962) is:

$$
k_{f}=2\left(r_{a}+r_{b}\right)^{2}\left(\frac{2 \pi k_{b} T}{\mu}\right)^{1 / 2} \exp \left(-\frac{E_{a}}{k_{b} T}\right) .
$$

here $r_{a}$ and $r_{b}$ - the covalent radii of the interacting particles, $\mu=\frac{m_{a} m_{b}}{m_{a}+m_{b}}$ - the reduced mass and $m_{a}, m_{b}$ - the interacting particles masses. So the constant of the first chemical reaction (11) under the boiling temperature is $3.245 \cdot 10^{-16} \mathrm{~m}^{3} / \mathrm{sec}$ for titanium, and $6.283 \cdot 10^{-17}$ $\mathrm{m}^{3} / \mathrm{sec}$ for copper.

The mass loss from the solid surface in the presence of negatively charged particles in the flow should be considered as a charged continuum flow with a double electrical layer creation. In this case, the mean free path of every negative ion in the flow must be significantly 
smaller than the distance, i.e. the negative ions to be removed without the collision in the double electrical layer. So

$$
\bar{l}<<l_{0}=\frac{m_{a} v_{f}^{2}}{2 e E_{e}} .
$$

Here $m_{a}$ - the particle mass in the cathode flame, $E_{e}=\frac{N_{c l} e}{S_{k} \varepsilon_{0}} W$ the electric field strength of the charged cathode spot surface $S_{k}$ and $\varepsilon_{0}=$ $8.854 \cdot 10^{-12} \mathrm{~F} / \mathrm{m}$ - dielectric vacuum permeability.

There are the electric field intensity values in the double electric layer and its layer size in Table 1.

Table 1 - Main parameters of the double electrical layer Таблица 1 - Основные параметры двойного электрического слоя Tabela 1 - Nominalni parametri dvostrukog električnog sloja

\begin{tabular}{|c|c|c|c|c|c|c|c|c|}
\hline $\begin{array}{c}\text { Pathode } \\
\text { material }\end{array}$ & $\begin{array}{c}U_{k,} \\
\mathrm{~V}\end{array}$ & $\begin{array}{c}\mathrm{E}_{\mathrm{e}}, \\
\mathrm{V} / \mathrm{m}\end{array}$ & $\begin{array}{c}V_{f}, \\
\mathrm{~m} / \mathrm{sec}\end{array}$ & $\begin{array}{c}\Delta, \\
\mathrm{m}\end{array}$ & $\begin{array}{c}C_{p,}, \\
\mathrm{~J} / \mathrm{kg} \cdot \mathrm{K}\end{array}$ & $\begin{array}{c}\rho_{\mathrm{e}}, \\
\mathrm{V} \cdot \mathrm{m}\end{array}$ & $\begin{array}{c}l_{0}, \\
\mathrm{~mm}\end{array}$ & $\begin{array}{c}T_{p}, \\
\mathrm{~K}\end{array}$ \\
\hline iron & 11.8 & 481 & 4324 & $2.35 \cdot 10^{-4}$ & 975 & $8.6 \cdot 10^{-8}$ & 11.2 & 2650 \\
\hline titanium & 6.8 & 459 & 4652 & $3.55 \cdot 10^{-4}$ & 684 & $4.2 \cdot 10^{-7}$ & 11.7 & 2270 \\
\hline copper & 11.3 & 1060 & 7820 & $4.84 \cdot 10^{-4}$ & $451 / 513$ & $1.6 \cdot 10^{-8}$ & 19.5 & 2070 \\
\hline
\end{tabular}

The mean free path in the discharge chamber is:

$$
\bar{l} \cong \frac{4 r_{k}}{\sqrt{2} N_{c l} W} .
$$

where $P_{C}$ - the cathode flame pressure and $r_{k}$ - the radius of particles of the cathode flame (atoms for titanium and copper). The mean free path in the cathode flame is $2.76 \cdot 10^{-10} \mathrm{~m}$ for titanium atoms, $2.28 \cdot 10^{-10} \mathrm{~m}$ for iron and $1.86 \cdot 10^{-10} \mathrm{~m}$ for copper, while the distance, the negative ions to be removed from the cathode spot surface, is $5.5 \mathrm{~mm}, 11 \mathrm{~mm}$ and $12 \mathrm{~mm}$ for iron, titanium, and copper, respectively. The condition (15) is satisfied, so the cathode flame should be considered as a charged continuum flow. In such a flow, the negative ion range distance from the cathode spot surface is determined not only by the slowing down of the charged particles in the electric field of the double layer, but also by their ionization due to the reaction (11). Then the free electrons concentration along the axis $X$ at the distance $\mathrm{x}$ in the layer $\mathrm{dx}$ is defined from the chemical reactions and slowing down in the double electrical layer in the following way:

$$
d n_{e}=k_{f} n_{a} n_{i}^{-} \frac{d x}{v_{0}-\frac{e E_{e}}{m_{a} v_{0}} x} .
$$


The solution of the differential equation in terms of the boundary condition offers the following approximate dependence for the first and second reaction (11) to occur in the flame

$$
\begin{aligned}
& n_{e}(x)=n_{e, 0}+2 k_{f, 1} n_{a} \operatorname{grad}\left(n_{i}^{-}\right) \frac{m_{a} v_{0}}{e E_{e}} x ; \\
& n_{e}(x)=n_{e, x}+2 k_{f, 2} n_{e} \operatorname{grad}\left(n_{i}^{-}\right) \frac{m_{a} v_{0}}{e E_{e}} x,
\end{aligned}
$$

where $n_{\mathrm{e}, 0}$ - the initial free electrons concentration to be determined by the boiling temperature using the Saha equation.

The first reaction (11) takes place at the beginning and the highenergy ions are generated. After their appearance, the negative ions ionization by an electron impact is stimulated with the decreasing of the quick energy of exciting and forming electrons. Thus, free electrons are generated at the distance of $\Delta l \sim 10^{-2} \mathrm{~m}$ from the cathode spot surface in accordance with reaction (11). Free electrons under the influence of the positively charged cathode spot surface are directed to the cathode, generating a reverse electric current which is equal to:

$$
I=e n_{e, x} \bar{v}_{e} S_{k} .
$$

where $\bar{v}_{e}$ - the drift electron velocity in the cathode flame plasma.

The following equality is true under stationary conditions on the basis of the charge conservation law

$$
n_{i}^{-} v_{f} S_{k, P}=n_{e, k} \bar{v}_{e} S_{k} .
$$

On the basis of (20), the reverse electric current is equal to the electric current to be generated during a cluster explosion, i.e. to the electric charge separation current with creating a double electrical layer. The difference is that the charge separation current lasts during the clusters explosion, while the reverse current lasts during the creation of the double electrical layer. The direct current is determined by the complex exploded cluster, while the reverse current - by the whole cathode spot surface. As a result, the reverse current density is an order of magnitude lower than the charge separation current.

The complete ionization of negative ions takes place at the distance of the full ions slowing down and in fact the reverse current stops. In this moment, the cathode spot stops its functioning at the given place and the cathode spot is generated alio loco. The cathode spot duration is $2.6 \cdot 10^{-6}$ $\mathrm{sec}$ without dependence on the cathode material and it turns out to be the cathode spot lifetime. If the breakdown of the near-cathodic space 
takes place inside the cathode space, then the cathode spot lifetime increases. This fact was experimentally proved and the most probable value was in a great agreement with data listed here (Kesaev, 1968).

Since the reverse current is transferred by electrons, they can penetrate to the skin depth $(\Delta)$. The specific skin layer values for some materials are listed in Table 1. The temperature of the skin layer to be heated, is:

$$
T_{p}=T_{0}+\frac{j_{k} U_{k} l_{0}}{\Delta \rho C_{p} v_{f}} .
$$

The results of the temperature evaluations and the skin layer to be heated in the cathode layer are listed in Table 1. The surface layer heating in the cathode spot for all the metals is not higher than the boiling temperature and is slightly higher than the melting point.

The cathode spot temperature measured experimentally by an optical pyrometer under different discharge conditions was in the range of $1300-$ $2300 \mathrm{~K}$, and $2300-3700 \mathrm{~K}$ for the copper arc. The temperature evaluations listed in Table 1 are in good agreement with experimental data and are within the melting point and the boiling temperature.

\section{Electronic component temperature in the cathode flame}

As a result of the first reaction of (11), the electrons are in the surroundings with average energy, which is equal to the difference between the diatomic molecule dissociation energy and the affinity energy:

$$
E_{e}=D-\theta_{i}^{-} .
$$

$E_{e}=1.2-0.163=1.037 \mathrm{eV}$ for iron, $E_{e}=1.2-0.079 \approx 1.121 \mathrm{eV}$ for titanium and $E_{e}=2.05-1.228 \approx 0.822 \mathrm{eV}$ for copper. Such average energy of the generated electrons is enough for titanium and copper to effectively ionize by the electron impact the remaining negative ions in accordance with the second reaction (11). These free electrons during negative ions ionization generate a cloud of free electrons with an average energy of (Gretchikhin, Kudryashov, 1970)

$$
\bar{\theta}_{e}=0,55 \theta_{i}^{-} \mathrm{eV} \text {. }
$$

For example, in the cathode flame, consisting of iron vapor, where the continuous negative ions disintegration due to the electron impact takes place, the average electrons energy in plasma is $0.09 \mathrm{eV}$, and it corresponds to the electron gas temperature $T_{e, 2}=1040 \mathrm{~K}$; , the average 
electrons energy for the titanium vapor is $0.0435 \mathrm{eV}$, so the electron gas temperature is $T_{\mathrm{e}, 2} \sim 505 \mathrm{~K}$; while for the negative copper ions it is $0.452 \mathrm{eV}$ with an average-effective temperature of $T_{\mathrm{e}, 2} \sim 5243 \mathrm{~K}$. So, for the vacuum arc discharge plasma in iron and titanium vapor, the electron gas energy is primarily defined by the first reaction of (11) and the values are 0.570 and $0.616 \mathrm{eV}$, while the temperatures are $\sim 6620$ and $7152 \mathrm{~K}$, respectively. For the arc discharge copper plasma, in the first reaction the electrons are generated into plasma with $0.452 \mathrm{eV}$, while in the second reaction, with $0.675 \mathrm{eV}$. The second reaction of (11) leads to a quick electron gas temperature drop in the titanium atmosphere, just on the contrary to the copper atmosphere. So, the electron subsystem in the vapor-gas phase of iron, titanium and copper in the cathode flame has an expressed two-humped energies distribution.

Every electron generated after the first reaction (11) excites the following number of direct negative ions by means of the second reaction of (11):

$$
\eta_{i} \approx \frac{1}{3,5} \cdot \frac{E_{1}}{E_{2}} \int_{3,5 \cdot E_{2}}^{\infty} f\left(E, T_{1}\right) d E .
$$

where $E_{1}$ - the average energy of the generated electrons owing to the first reaction of (11) and $E_{2}$ - owing to the second reaction of (11). The factor 3.5 is determined by the maximum ionization cross-section during the electron impact. (Physical magnitudes: Handbook, 1991)

The final distribution of the generated electrons due to negative ions ionization:

$$
f(E) d E=\frac{\left[f_{1}\left(E, T_{1}\right)+f_{2}\left(E, T_{2}\right)\right] d E}{\int_{0}^{\infty}\left[f_{1}\left(E, T_{1}\right)+f_{2}\left(E, T_{2}\right)\right] d E} .
$$

In copper vapors, the electron gas temperature corresponds mainly to the second reaction of (11). Bearing in mind that there is the electron subsystem in the thermodynamic equilibrium, the average temperature of the vacuum discharge electron component in the copper vapors is $\sim 7830 \mathrm{~K}$. The average electron flame temperature was calculated near the surface by modeling the energy fluxes to occur in the cathode spot of the vacuum arc by means of laser, carried out by (Gretchikhin, Minko, Ya, 1967), and it was $7900 \mathrm{~K}$. This coincidence was quite convincing within measurement errors.

So the electron component temperature is defined by the negative ions ionization processes. When the flame leaves the cathode surface drop, it has the temperature which is equal to the cathode material boiling temperature. And the electron flame temperature increases when the 
distance from the cathode surface increases too. This was experimentally found here (Gretchikhin, Tyunina, 1967), (Gretchikhin, Davydov, Minko, Ya, 1968), (Gretchikhin, Minko, Ya, 1968), (Gretchikhin, 1974).

The following fact was found experimentally in these studies (Gretchikhin, Tyunina, 1967), (Gretchikhin, Davydov, Minko, Ya, 1968), (Gretchikhin, Minko, Ya, 1968), (Gretchikhin, 1974). High-power continuous radiation can appear near the cathode surface, but the spectral lines and bands radiation of atoms and molecules are absent. So the flame emission near the cathode surface corresponds to the condensed media, i.e. in this case it is a liquid phase. The separation between the vapor-gas and the liquid phase takes place as the distance from the cathode surface increases. The temperature quickly increases in the vapor-gas phase and atoms and molecules radiation takes place, while the liquid phase radiation disappears due to its cooling under the dispersion.

The electrons are directed onto the cathode as the negative ions disintegration and they neutralize the induced positive charge, spread all over the cathode spot. The positive ions from the discharge gap cannot reach the cathode surface, since they are neutralized during the impact with the cathode flame. The current from the discharge onto the cathode stops and so the near-cathodic area breakdown takes place in the other place and this is determined by the fact that the opposite currents are mutually repelled.

If we assume that there is vacuum arc discharge plasma in the thermodynamic equilibrium, the ion plasma composition in the cathode flames vapor inside the discharge gap can be defined by the Saha equation:

$$
\frac{n_{i+1} n_{e}}{n_{i}}=C^{\prime} \frac{2 Z_{i+1}}{Z_{i}} \exp \left(-\frac{\varepsilon_{i+1}-\varepsilon_{i}}{k_{b} T}\right),
$$

where $C^{\prime}=\frac{\left(2 \pi m_{e} k_{b} T\right)^{3 / 2}}{h^{3}}=2,415 \cdot 10^{21} T^{3 / 2}-$ the dimensional constant; $Z_{i+1}, Z_{i}$ - the statistical partition function; $\varepsilon_{i+1}, \varepsilon_{i}$ - the energy of state $i+1$ and $i$ the degree of ionization of plasma particles, $k_{b}$ - the Boltzmann constant, $T$ - the corpuscular heated vapor temperature, $m_{\mathrm{e}}-$ the electron mass and $h-$ the Planck constant.

Table 2 - lons per cent of different degree of ionization

Таблица 2 - Процент ионов разной кратности ионизации

Tabela 2 - Procenat jona različitog stepena jonizacije

\begin{tabular}{|c|l|c|c|c|}
\hline \multirow{2}{*}{ Element } & \multirow{2}{*}{$U_{\mathrm{k}}}$, & \multicolumn{3}{|c|}{ Ions fraction, \% } \\
\cline { 3 - 5 } & $\mathrm{V}$ & $\mathrm{I}$ & $\mathrm{II}$ & $\mathrm{III}$ \\
\hline $\mathrm{Ti}$ & 6.8 & $27 / 27$ & $72 / 67$ & $1 / 6$ \\
\hline $\mathrm{Cu}$ & 11.3 & $30 / 30$ & $68 / 54$ & $1.9 / 15$ \\
\hline
\end{tabular}


The direct measurements of the composition by percentage of ions with different degrees of ionization were carried out in the vacuum arc discharge at a current of $100 \mathrm{~A}$. (Mrochek, Vershina, Ivashchenko, et al, 2004) and (Kolesnik, Kolesnik, 2009) and the results are listed in Table 2 (the lower row). If we make the association with the composition by percentage of ions with the first degree of ionization, then, in accordance with the Saha equation, the temperature is $\sim 4100 \mathrm{~K}$ for the titanium cathode and $6830 \mathrm{~K}$ for the copper cathode. Under these temperatures, the composition measurements by percentage of ions with consequent degrees of ionization in the vacuum discharge are listed in Table 2 (the upper row). The found results of the composition by percentage using the Saha equation do not obviously correspond to the composition by percentage obtained by direct measurements. It indicates that the generated plasma in the vacuum arc discharges is essentially no equilibrium. There is a difference between the electronic temperature and the atomic temperature obtained by the Saha equation. The electronic component in the vacuum arc plasma discharge has the electrons with different energy, i.e. their generation takes place due to the different mechanisms on the basis of reactions in (11).

\section{Electric current reverse motion in the cathode flame under the tangential magnetic field}

It was found experimentally by Shtark and then by Keasev in detail, that the reverse current rate of the cathode spot under the longitudinal magnetic field depends on:

- cathode material;

- cathode material surface condition;

- arc current;

- oxide film;

- cathode temperature; and

- pressure of reaction discharge gas in the chamber.

The simultaneous explosions of several clusters (emission cells systems) in the cathode spot leads to the double electrical layer generation above the cathode spot of a sufficiently great size $\left(I_{0}\right.$ Table 1$)$. The electrical current of neutralization of the positive charge on the cathode spot surface in the double electrical layer is directed oppositely to the principal discharge current. The Ampere force appears under the magnetic field superposition along the cathode surface:

$$
\vec{F}_{A}=-[\vec{J} \cdot \vec{B}] S_{k} l_{0} .
$$


Hence, the cathode spot rate of motion is:

$$
v_{n}=\frac{F_{A}}{m_{k}} \frac{l_{0}}{v_{f}}=-\frac{l_{0}^{2}}{m_{k} v_{f}}[\vec{J} \cdot \vec{B}] S_{k},
$$

where $m_{k}$ - the cluster mass.

Let it be examined in what way the above-mentioned changing parameters have the influence on the cathode spot velocity of reverse travel under the longitudinal magnetic field.

The material cathode dependence is directly proportional to the dependence on the squared double electrical layer width and inversely proportional to the dependence on the cluster mass and flame rate of motion for different materials. The titanium cathode spot rate of motion is 5.8 times higher than the one for iron, while for copper it is 7.2 times higher.

The dependence on the surface condition (i.e. roughness) occurs when the cathode spot fails and recovers in another area, but the transition from one hill to another with a roughness increase cannot take place and the cathode spot motion stops.

The cathode spot rate of motion increases directly proportionally to the arc current under constant other parameters.

The oxide film on the cathode material prevents the near-cathodic space breakdown and it can lead to the quick cathode spot motion stop.

The cathode temperature increase leads to the thermo emission current increasing, which reduces the reverse electron neutralization current of the double electrical layer. Therefore, it decreases the Ampere force and, consequently, the cathode flame rate of reverse motion.

The increase of the pressure of reaction discharge gas in the chamber leads to the increase of the positive ions concentration in the discharge gap. The cathode flame is bombarded by positive ions, the negative ions concentration is decreased and, consequently, free electrons concentration during the negative ions ionization is decreased, too. The reverse electric current is reduced and the cathode spot rate of reverse motion is decreased.

\section{Conclusion}

Therefore, the investigations of the vacuum arc discharge with the cold cathode allowed finding out a new phenomenon. During the generation of a defined complex clusters explosion in the cathode spot, a fraction of certain atoms is as negative ions. As a result of this, a double electrical layer is formed above the cathode spot, and its neutralization leads to reverse current of free electrons generated owing to the negative ions ionization. 
This phenomenon in the cathode spots of the arc discharges allowed finding out the following:

1. The negative charged flame with frequency, defined by the cathode spot life time discharges from the cathode spot,

2. The double electrical layer is generated above the cathode spot surface, which is neutralized by the reverse electrical current, generated by free electrons owing to the negative ions ionization,

3. All the phenomena taking place during the cathode spot motion under the longitudinal magnetic field are explained by the high-power reverse neutralization current generation of the double electrical layer.

\section{Literature}

Бабичев, А.П., Бабушкина, N.А., Братковский, А.М., \& и др, 1991. Физические величины: Справочник. U И.С. Григорьева\& Е.3. Мейлихова Ur., .Москва: Энергоатомиздат., стр.1232. (Babichev, A.P., Babushkina, N.A., Bratkovskiy, A.M., et al. 1991. Physical Quantities: Reference Book. Edited by Grigoriev, I.S., Meilikhov, E.Z.Moscow, Energoatomizdat, p.1232).

Балдаев, Л.Х., Борисов, В.Н., \& Вахалкин, В.А. 2007. Газотермическое напыление. U Л.Х. Балдаева Ur., Учебное пособие для вузов.Москва: Маркет ДС., стр.344. (Baldaev, L.K., Borisov, V.N., \& Vakhalkin, V.A. 2007. Thermal Spraying. Handbook for Higher Education Institutions. / Edited by L. K. Baldaev. - Moscow: Market DS, p.344).

Бенсон, С. 1962. Основы химическој кинетики .Москва: Мир., стр.603. (Benson, S. 1962. The Foundations of Chemical Kinetics. Moscow: Mir, p.603).

Гречихин, Л.И. 1974. Разделение электрических зарядов на поверхности твердого тела. Минск: МВИЗРУ., стр.222. Диссертация на соискание ученой степени доктора физико-математических наук. (Gretchikhin, L.I. 2004. Separation of electric charges on the surface of a solid. Thesis for the degree of Doctor of Science in physics and mathematics. Minsk, Minsk Higher Engineering Antiaircraft Missile School, p.222).

Гречихин, Л.И. 2008. Наночастицы и нанотехнологии.Минск: Право и экономики., стр.406. (Gretchikhin, L.I. 2008. Nanoparticles and Nanotechnologies. Minsk: Law and Economics, p.406.)

Гречихин, Л.И. 2008. Физика. Электричество и магнетизм. U Современная электродинамика. Минск: Право и экономики, стр.302. (Gretchikhin, L.I. 2008. Physics. Electricity and Magnetism. Minsk: Law and Economics, p.302).

Гречихин, Л.И., Давыдов, В.Б., \& Минько, Л.Я. 1968. Исследования приэлектродных плазмообразований сильноточного разряда с разделенными факелами при атмосферном давлении. Теплофизика высоких температур, 5. (Gretchikhin, L.I., Davydov, V.B., \& Minko, L.Y. 1968. Studies of near-electrode plasma formations of heavy-current discharge with separated flares at atmospheric pressure. "Thermal Physics of High Temperatures", 5).

Гречихин, Л.И., \& Кудрјашов, В.В. 1970. Известија Вузов "Физика", 9. (Gretchikhin, L.I., \& Kudryashov, V.V. 1970. Proceedings of the Higher Educational Institutions. Physics, 9.

Гречихин, Л.И., \& Минько, Л.Я. 1967. Об аналогии фризических процессов, протекающих в импульсном разряде и при воздействии концентрированного лазерного излучения. ЖТФ, 37. (Gretchikhin, L.I., \& Minko, L.Y. 1967. About the analogy of physical processes taking place in impulse discharge and when exposed to concentrated laser radiation. Technical Physics, 37). 
Гречихин, Л.И., \& Рублева, О.И. 2006. Взрывные технологии в шахтном строительстве. U Вестник. Современные проблемы шахтного и подземного строительства.Донецк: Норд-Пресс., стр.100-110. (Gretchikhin, L.I., \& Rubleva, O.I., 2006. Blasting technologies in mining constructions. Vestnik. Modern problems in mining and underground constructions Donetsk, Nord-Press, pp.100-110).

Гречихин, Л.И., \& Тюнина, Е.С. 1967. Исследования электродных фракелов дугового разряда. Журнал «Физика и химия обработки материалов», 11(3), стр.27-28 (Gretchikhin, L.I., \& Tyunina, E.S., 1967. Studies on Electrode Flares of Arc Discharge. Journal "Physics and Chemistry of Materials Processing", 11(3). pp.27-28).

Григоряанц, А.Г. 1989. Основы лазерној обработки материалов.Москва: Машиностроение., стр.304. (Grigoryants, A.G. 1989. The basics of Laser Materials Processing. Moscow: Mashinostroenie, p.304).

Кесаев, И.Г. 1968. Катодные процессы электрической дуги.Москва: Наука., стр.186. (Kesaev, I.G. 1968. Cathode Processes of the Electric Arc. Moscow: Nauka, p.186).

Колесник, В.П., \& Колесник, В.В. 2009. Технологические генераторы плазмы. U Курс лекций для ВУЗов.Киев: Миллениум., стр.92. (Kolesnik, V.P., \& Kolesnik, V.V. 2009. Technological Plasma Generators. Course of Lectures for Higher Educational Institutions. Kiev, Millennium, p.92.)

Коробејников, В.П., Мельникова, Н.С., \& Рјазанов, Е.В. 1961. Теория точечного взрыва.Москва: Физматгиз., стр.332. (Korobeinikov, V.P., Melnikov, N.S., \& Ryazanov, E.V. 1961. Theory of Point Explosion. Moscow: Phismatgiz, p.332).

Костенбојм, Х.С. 1974. Точечный взрыв. Методы расчета. Таблицы.Москва: Наука., стр.255. (Kostenboim, K.S. 1974. Point Explosion. Methods of Calculation. Tables. Moscow, Nauka, p.255.)

Литвинский, Г.Г. 2006. Методика расчета взрыва заряда на выброс. UВестник. Современные проблемы шахтного и подземного строительства.Донецк: НордПресс., стр.117-131. (Litvinskiy G.G. 2006. Methods of Calculating the Crater Charge. Vestnik. Modern problems in mining and underground constructions. Donetsk, NordPress, pp.117-131).

Месси, Г. 1979. Отрицательные ионы.Москва: Мир., стр.754. (Massey, Н. 1979. Negative lons. Moscow: Mir, p.754).

Месяац, Г.А. 1993. Эктоны в электрических разрядах. Письма в ЖЭТФ, 57(1-2). (Mesyats, G.A. 1993. Ectons in Electric Discharges. JETP Letters, 57(1-2).

Месяац, Г.А. 1995. Ёктон - лавина ёлектронов из металла. УФН, 165(6). (Mesyats, G.A. 1995. Ecton or Electron Avalanche from Metal. Advances in Physical Sciences, 165(6).

Месяц, Г.А. 2000. Эктоны в вакуумном разряде: пробой, искра, дуга.Москва., cтp.424. (Mesyats, G.A. 2000. Ectons in a Vacuum Discharge: Breakdown, Spark, Arc. Moscow, p.424).

Мрочек, Ж.А., Вершина, А.К., Ивашченко, С.А., \& и др., 2004. Плазменновакуумные покрытия / Plasma vacuum coating. Минск: УП «Технопринт»., стр.369. (Mrochek, Z.A., Vershina, A.K., Ivaschenko, S.A., et al. 2004. Plasma Vacuum Coating. Minsk: UE "Technoprint", p.369).

Радциг, А.А., \& Смирнов, Б.М. 1980. Справочник по атомной и молекулярной фризике.Москва: Атомиздат., стр.240. (Radtsig, A.A., \& Smirnov, B.M. 1980. Reference Book on Atomic and Molecular Physics. Moscow: Atomizdat, p.240.) 


\section{ДВОЙНОЙ ЭЛЕКТРИЧЕСКИЙ СЛОЙ В КАТОДНОМ ПЯТНЕ}

Леонид И. Гречихин ${ }^{\mathrm{a}}$, Светлана Д. Латушкина ${ }^{\text {, }}$

Виктория М. Комаровская

а Белорусская государственная академия связи, г. Минск,

Республика Беларусь,

б Физико-технический институт НАН Беларуси, г. Минск,

Республика Беларусь,

${ }^{\text {в} Б е л о р у с с к и и ̆ ~ н а ц и о н а л ь н ы и ̆ ~ т е х н и ч е с к и и ̆ ~ у н и в е р с и т е т, ~ г . ~ М и н с к, ~}$

Республика Беларусь

ОБЛАСТЬ: материалы, нанотехнология, материаловедение на наноуровне

ВИД СТАТЬИ: оригинальная научная статья

ЯЗЫК СТАТЬИ: анлийский

Краткое содержание:

Установлено новое явление, заключающееся в образовании над поверхностью катодного пятна двойного электрического слоя, нейтрализация которого приводит к обратному току свободными электронами, образующихся вследствие ионизации отрицательных ионов. Отрицательно заряженный фракел из катодного пятна периодически пропадает и возникает. Этот колебательный процесс определяет длительность существования катодного пятна. Обратное движение катодного пятна в продольном магнитном поле происходит вследствие образования обратного мощного тока нейтрализации двойного электрического слоя электронами, возникающих при ионизации отрицательных ионов в катодном фракеле.

Ключевые слова: электрический разряд, катодное пятно, катодный факел, отрицательные ионы, двойной электрический слой.

\section{DVOSTRUKI ELEKTRIČNI SLOJ U KATODNOM SPOTU}

Leonid I. Grečihin ${ }^{a}$, Svetlana D. Latuškina ${ }^{b}$, Viktorija M. Komarovskaja ${ }^{c}$

${ }^{a}$ Beloruska državna akademija za saobraćaj i veze, Minsk,

Republika Belorusija

b Institut za fiziku i tehničke nauke Državne akademije nauka, Minsk,

Republika Belorusija

${ }^{\mathrm{c}}$ Beloruski nacionalni tehnički univerzitet, Minsk, Republika Belorusijja

OBLAST: materijali, nanotehnologije

VRSTA ČLANKA: originalni naučni članak

JEZIK ČLANKA: engleski 
Sažetak

$U$ radu se opisuje novootkrivena pojava stvaranja dvostrukog električnog sloja iznad površine katodnog spota. Njegova neutralizacija dovodi do reverzne struje slobodnih elektrona, generisane usled jonizacije negativnih jona. Negativno naelektrisan plamen katodnog spota periodično se stvara i gasi, tako da je dužina postojanja katodnog spota definisana ovim oscilirajućim procesom. Reverzno kretanje katodnog spota u longitudinalnom magnetnom polju dešava se zahvaljujući generisanju reverzne struje neutralizacije velike snage dvostrukog električnog sloja pomoću elektrona koji nastaju tokom jonizacije negativnih jona u plamenu katode.

Ključne reči: električno pražnjenje, katodni spot, plamen katode, negativni joni, dvostruki električni sloj.

Paper received on / Дата получения работы / Datum prijema članka: 25. 12. 2015.

Manuscript corrections submitted on / Дата получения исправленной версии работы / Datum dostavljanja ispravki rukopisa: 27. 03. 2016.

Paper accepted for publishing on / Дата окончательного согласования работы / Datum konačnog prihvatanja članka za objavljivanje: 29. 03. 2016.

() 2016 The Authors. Published by Vojnotehnički glasnik / Military Technical Courier (www.vtg.mod.gov.rs, Втг.мо.упр.срб). This article is an open access article distributed under the terms and conditions of the Creative Commons Attribution license (http://creativecommons.org/licenses/by/3.0/rs/).

(c) 2016 Авторы. Опубликовано в "Военно-технический вестник / Vojnotehnički glasnik / Military Technical Courier" (www.vtg.mod.gov.rs, втг.мо.упр.срб). Данная статья в открытом доступе и распространяется в соответствии с лицензией "Creative Commons" (http://creativecommons.org/licenses/by/3.0/rs/). 